\title{
Transcatheter drug delivery through bronchial artery for COVID-19: is it fiction or could it come true?
}

\author{
Mohamed M. A. Zaitoun ${ }^{1 *}$ D, Mohammad Abd Alkhalik Basha and Ali Hassan Elmokadem²
}

\begin{abstract}
More than 1,200 active or recruiting clinical trials for novel coronavirus disease 2019 (COVID-19) treatments and vaccines are registered. Many drugs have shown promise for treatment of COVID-19. Nevertheless, up to date, no drugs have been confirmed as a definitive treatment for COVID-19. Trials such as the SOLIDARITY and RECOVERY are ongoing, and first results were announced in favour of therapy with dexamethasone with a significant trend showing greatest benefit among those patients requiring ventilation. The drawbacks of these trials include exposing the patients to drugs with well-documented systemic adverse effects or unknown complications of novel therapies without proof of clinical benefit. We present here the hypothesis that bronchial artery infusion could be an alternative for systemic drug infusion in COVID-19 trials with superadded benefits of high drug concentration and low systemic adverse effects. The concept of this idea has many uncertainties and no current clinical data to support. Perhaps, the technique should be first applied in animal models to determine its safety and calculate the effective dose of the drugs. Guidelines and reviews of pharmacotherapy for COVID-19 should be implemented for this fiction to come true.
\end{abstract}

Keywords: Angiography, COVID-19, Bronchial arteries, Pandemics, Severe acute respiratory syndrome coronavirus 2 (SARS-CoV-2)

\section{Key points}

- COVID-19 is a global pandemic.

- Many active clinical trials of COVID-19 treatments and vaccines are registered.

- Bronchial artery infusion (BAI) could be an alternative for systemic drug infusion in COVID-19 trials.

The novel coronavirus disease 2019 (COVID-19) is a highly infectious disease caused by a severe acute respiratory syndrome coronavirus (SARS-CoV-2) which started in Wuhan, China, in December 2019. The World

\footnotetext{
* Correspondence: Zaitoun82@gmail.com

${ }^{1}$ Diagnostic Radiology Department, Faculty of Medicine, Zagazig University, Zagazig, Sharqiyah, Egypt

Full list of author information is available at the end of the article
}

Health Organization (WHO) declared COVID-19 a global pandemic on March 11, 2020 [1]. Overall, there have been 8,242,999 confirmed cases and 445,535 deaths distributed across the globe as of June 18, 2020 [2]. While COVID-19 pandemic continues to spread, causing exponential morbidity and mortality, and threatening economies, the world is racing to find safe and effective treatments.

More than 1,200 active or recruiting clinical trials for COVID-19 treatments and vaccines are registered [3]. Several agents are being investigated as potential therapies for COVID-19. Many drugs have shown high promise for treatment of COVID-19 such as immunomodulatory, anti-inflammatory, antiviral, and antiparasitic agents. Nevertheless, up to date, no drugs have been confirmed as a definitive treatment for COVID-19.

\section{Springer Open}

(c) The Author(s). 2020 Open Access This article is licensed under a Creative Commons Attribution 4.0 International License, which permits use, sharing, adaptation, distribution and reproduction in any medium or format, as long as you give appropriate credit to the original author(s) and the source, provide a link to the Creative Commons licence, and indicate if changes were made. The images or other third party material in this article are included in the article's Creative Commons licence, unless indicated otherwise in a credit line to the material. If material is not included in the article's Creative Commons licence and your intended use is not permitted by statutory regulation or exceeds the permitted use, you will need to obtain permission directly from the copyright holder. To view a copy of this licence, visit http://creativecommons.org/licenses/by/4.0/. 
On March 20, 2020, the WHO and partners announced the SOLIDARITY trial [4]. The SOLIDARITY trial is comparing three treatment options against the standard of care, to assess their relative effectiveness against COVID-19 and discover whether any of these drugs slow disease progression or improve survival. Treatment options under the study are the following: (i) remdesivir, a previously tested Ebola treatment; (ii) lopinavir/ritonavir, a licensed treatment for the human immunodeficiency virus (HIV) infection; and (iii) interferon- $\beta-1 \mathrm{a}$, used to treat multiple sclerosis. The chloroquine and hydroxychloroquine arm was removed from the SOLIDARITY trial on June 17, 2020 [4].

The "Randomized evaluation of COVID-19 therapy" (RECOVERY) trial [5] is another randomised controlled clinical trial including 11,500 patients who have been randomised to the following treatment arms: (i) lopinavir-ritonavir; (ii) low-dose dexamethasone, an antiinflammatory steroid; (iii) azithromycin, an antibiotic; (iv) tocilizumab (an anti-inflammatory treatment); (v) convalescent plasma (collected from donors who have recovered from COVID-19); and (vi) hydroxychloroquine (which has been stopped). Overall, the 28-day mortality rate was reduced by $17 \%$ using dexamethasone with a highly significant trend showing greatest benefit among those patients requiring ventilation (test for trend, $p<0.001$ ) [5]. The drawbacks of these trials include exposing the patients to drugs with welldocumented systemic adverse effects or unknown complications of novel therapies without proof of clinical benefit.

Based on the first-pass effect of transcatheter therapy, we can hypothesise that bronchial artery infusion could be an alternative for systemic drug infusion in COVID19 trials with superadded benefits of high drug concentration and low systemic adverse effects. Studies demonstrated that the bronchial artery is the main feeding artery for lung tumours. Hence, bronchial artery infusion is used as a palliative treatment option for primary and metastatic lung cancers [6]. Additionally, transcatheter therapy for purposes other than tumour management was reported. Transcatheter arterial steroid injection therapy prevented the progression of severe acute hepatic failure to a fatal stage of fulminant liver failure in 13 out of 17 patients [7].

However, the situation is different for COVID-19 as the exact pathophysiologic mechanism of ground-glass opacities is still unclear, and the possibility of being fed by bronchial arteries is not proven as in case of lung neoplasms. Furthermore, the blood flow into the lung in cases of pneumonia might be reduced as reported before in experimental animals [8]. The other major obstacle is how to prepare the angiographic suite for COVID-19 to control the spread of infection to the intervention radiology staff and other patients. Ierardi et al. [9] reported strict preprocedural, intraprocedural, and postprocedural workflow measures in the setting of an IR unit that is highly exposed to COVID-19. These safe practices may raise the equipment cost, prolong procedural times, and increase technical difficulties.

The search for successful therapies for COVID-19 infection is a challenging process. To the best of our knowledge, no previous reports or registered trial was proposing the transcatheter drug delivery through the bronchial artery to treat COVID-19. Proposed drugs for transcatheter therapy are drugs evaluated by SOLIDARITY and RECOVERY trials in addition to anticoagulant therapy that were associated with a better outcome.

The concept of this idea has many uncertainties and no current clinical data to support. Perhaps, the technique should be first applied in animal models to determine its safety and calculate the effective dose of the drugs. Guidelines and reviews of pharmacotherapy for COVID-19 should be implemented for this fiction to come true.

\section{Abbreviations \\ COVID-19: Coronavirus disease 2019; SARS-CoV-2: Severe acute respiratory syndrome coronavirus}

\section{Acknowledgements \\ To the memory of the medical workers all over the world who paid their lives while fighting the COVID-19.}

\section{Authors' contributions}

MMAZ is the main author who suggested the idea, wrote the manuscript, and did the edit and the revision. MAB. and AHE assisted in the writing of the manuscript and in the revision procedure. The author(s) read and approved the final manuscript.

\section{Funding}

No funding was received.

\section{Availability of data and materials \\ Not applicable}

Ethics approval and consent to participate

Not applicable

Consent for publication

Not applicable

Competing interests

No conflict of interest.

\section{Author details}

${ }^{1}$ Diagnostic Radiology Department, Faculty of Medicine, Zagazig University, Zagazig, Sharqiyah, Egypt. 'Diagnostic Radiology Department, Faculty of Medicine, Mansoura University, Mansoura, Egypt.

Received: 18 June 2020 Accepted: 22 June 2020

Published online: 06 July 2020

\section{References}

1. World Health Organization (2020) WHO Director-General's opening remarks at the media briefing on COVID-19. 2020, March 11. https://www.who.int/ $\mathrm{dg} /$ speeches/detail/who-director-general-s-opening-remarks-at-the-mediabriefing-on-covid-19\%2D\%2D-11-march-2020 
2. World Health Organization (2020) Coronavirus Disease 2019 (COVID-19) Situation Reports - 150. 2020; 2020, June 18. https:/www.who.int/ emergencies/diseases/novel-coronavirus-2019/situation-reports

3. Clinicaltrials.Gov. (2020) Recruiting, active, not recruiting studies | Interventional studies for covid19. https://clinicaltrials.gov/ct2/results?cond= covid19\&recrs=a\&recrs=d\&age_v=\&gndr=\&type=Intr\&rslt=\&Search=Apply.

4. World Health Organization (2020) "Solidarity" clinical trial for COVID-19 treatments https://www.who.int/emergencies/diseases/novel-coronavirus-2 019/global-research-on-novel-coronavirus-2019-ncov/solidarity-clinical-trialfor-covid-19-treatments. 2020, June 18.

5. Statement from the chief investigators of the randomised evaluation of COVID-19 therapy (RECOVERY) trial on dexamethasone. Low-cost dexamethasone reduces death by up to one third in hospitalised patients with severe respiratory complications of COVID-19. https:/www. recoverytrial.net/news/low-cost-dexamethasone-reduces-death-by-up-toone-third-in-hospitalised-patients-with-severe-respiratory-complications-ofcovid-19. 2020, June18.

6. Bie Z, Li Y, Li B, Wang D, Li L, Li X (2019) The efficacy of drug-eluting beads bronchial arterial chemoembolization loaded with gemcitabine for treatment of non-small cell lung cancer. Thorac Cancer 10:1770-1778 https://doi.org/10.1111/1759-7714.13139

7. Kotoh K, Enjoji M, Nakamuta M et al (2006) Arterial steroid injection therapy can inhibit the progression of severe acute hepatic failure toward fulminant liver failure. World I Gastroenterol 12:6678-6682 https://doi.org/10.3748/wjg. V12..41.6678

8. Björk L, McNeil BJ (1977) Blood flow in pulmonary and bronchial arteries in acute experimental pneumonia and pulmonary embolism. Acta Radiol Diagn (Stockh) 18:393-399

9. lerardi AM, Wood BJ, Gaudino C et al (2020) How to handle a COVID-19 patient in the angiographic suite. Cardiovasc Intervent Radiol 43:820-826. https://doi.org/10.1007/s00270-020-02476-8

\section{Publisher's Note}

Springer Nature remains neutral with regard to jurisdictional claims in published maps and institutional affiliations.

\section{Submit your manuscript to a SpringerOpen ${ }^{\circ}$ journal and benefit from:}

- Convenient online submission

- Rigorous peer review

- Open access: articles freely available online

- High visibility within the field

- Retaining the copyright to your article

Submit your next manuscript at $\boldsymbol{\nabla}$ springeropen.com 